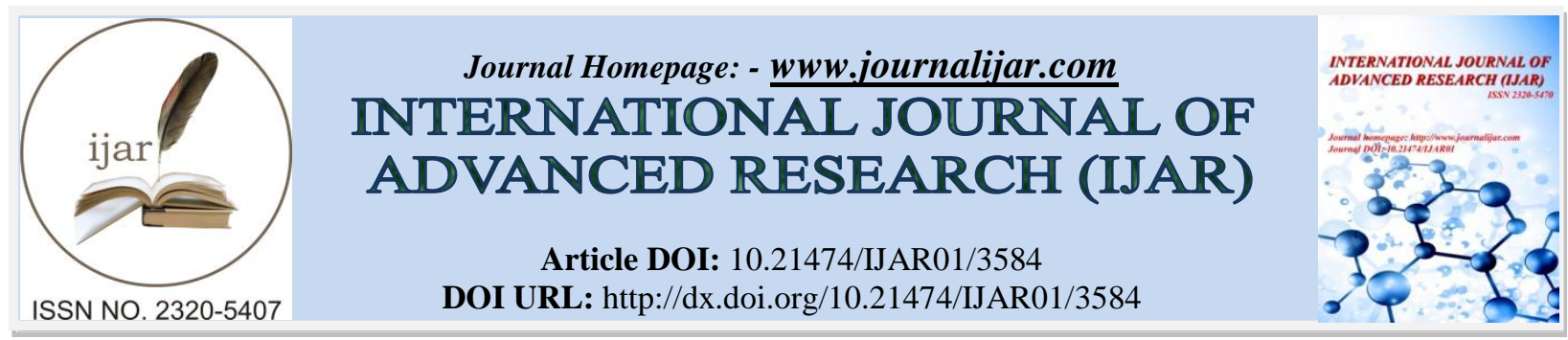

RESEARCH ARTICLE

\title{
CORPORATE SOCIAL RESPONSIBILITY: A STRATEGIC DECISION AND GOVERNANCE
}

Shabana Swarnakanth Kati.

M.A. M Phil. (English)

Assistant Professor, Department of English, K L University, Guntur, AP.

\section{Manuscript Info}

Manuscript History

Received: 04 January 2017

Final Accepted: 07 February 2017

Published: March 2017

\section{Abstract}

Corporate sector being one of the many investors in a corporate structure, it has been surveyed that all the companies possess Policies and practices of Corporate Social Responsibility (CSR). In the process of design and implementation of CSR by taking initiatives in the area of work, covers the entire community. Moreover, it has been unearthed that many companies carry out the promotion and implementation through Human Resource Department, in collaboration with NGOs but a full fledge CSR department. Nevertheless, CSR enterprises undertaken by the Indian companies for rural development created a positive impact on the inclusive development of business and society at large.

The vast majority of the poor in India has been gripped in the state of neglect and underdevelopment. The problems of illiteracy, mortality rate, ignorance, poor health and hunger are more serious issues in rural areas than in urban. The reason being merely, lack of equipment resources and defective planning investment process and model. India does have a potential to meet these tests in rural areas provided government efforts are sufficient to provide basic services to its citizens. It is alarmingly recognized that the progress and welfare of society is not just the responsibility of government rather other stakeholders also must give hand to achieve the goal of development.

The concept of CSR took birth basically in western world out of the public retort for the new stages of power and freedom that was acquired by transnational sectors due to continuous neo-liberal economic policies which were in practice in 1980s and 1990s initiated by the governments, then. Subsequently, the citizens of these nations felt discomfort with the mounting power of corporations when the media started exposing a few negative environmental and social impacts that the large chunk of Western owned corporations had in developing countries. Consequently, some academics, government agencies and development organizations thrust the responsibility on the part of corporations with a solution to lessen few of the negative impacts which would cater to contribute more to socioeconomic development in its largest sense.

Thus, the corporate sector does have an important role to play in ensuring that the private investment must reach these rural areas which have been neglected and remained out of development endeavour till now and looking forward to sustained development in rural areas, too. Surprisingly, many companies resulted in supporting the concept of CSR with the title of business of profit with due social responsibility. Very soon later the companies voluntarily decided to join hands with society to make it a cleaner and better environment (European Commission, 2001). Therefore, making CSR as "The commitment of businesses to contribute to sustainable development as well as to economic development by working with employers, their families, local community and society as a whole and 
improve their quality of life, so that it is good for business and for development. A widely-cited definition by the World Business Council for Sustainable Development the state of development that "Corporate Social Responsibility is the continuing commitment by business to behave ethically and contribute to economic development while improving the quality of life of workers and their families and the local community and society at large." (WBCSD, 1999)

Therefore, to define the CSR two folded, it could be stated that firstly, it offers ethics to the organization to practice for its inner and outer employees. Furthermore, it also makes the organization realize its responsibility towards the environment and the society in which it functions. Companies consider CSR as a means of giving the society its due returns. Undoubtedly, it is quite important to study and understand businesses and how they initiate CSR by creating their impact of activities in the domain of socio-economic development of the rural population. It is a mission to contribute innovative solutions to the environmental and social challenges. In order to identify the priorities and the CSR inventions in regard to rural development sector by the professional community, certain parameters must be drawn:

1. The objectives of CSR must be aligned with the Millennium Development Goals (MDGs).

2. The companies must create divisions assigned for CSR by comprising them with well qualified, well trained and well experienced professionals coming from social science background, Rural Development and Development Studies for better planning, application and evaluation.

3. CSR programmes which are to be put to action by the Indian companies must be founded on the felt needs of existing population through which their participation can be enhanced. Moreover, it should also be implied that the jobs are created by way of economic activities in the rural community to better their lives.

4. The performance of CSR of a company must come under social audits by external source agencies.

5. It would be unfair on the part of government to act just like a director of CSR. Rather, the government must take charge of being a facilitator, promotor and a catalyst to encourage the big players of the business world asking them to take into account the ethical, environmental and social issues of the country.

6. In order to highlight the company commitment to sustained development of the community, an annual report must be prepared on social responsibility.

It has been observed that companies have designed the policies of practicing CSR. A wide range of CSR initiatives which are designed and implemented ranges from agriculture development, drinking water management, development of natural resources, income generation schemes, health check-up and camps, health services on wheels, general and adult education and infrastructure services established by such companies. Although the manner of working is changing from philanthropic development to sustainable welfare, there doesn't seem to be any relation between company CSR plan and the Millennium Development Goals. It has also come to light that the companies carry out CSR initiatives through Human Resource Department, in collaboration with NGOs. There is an absence of full-fledged Corporate Social Responsibility department.

Thus, to conclude, CSR is surely considered as a vital issue of Indian companies no matter what its size, sector and objective or location is. Moreover, the Indian companies have realized that stability and sustainability of economic activities to compete with global market is not possible without socio-economic development of local communities. It has definitely resulted in the positive effect and impact on the overall development of society and business.

\section{References:-}

1. Maon, F., A. Lindgreen and V. Swaen, 2009. 'Designing and implementing Corporate Social Responsibility: An integrative framework grounded F in theory and practice', Journal of Business Ethics, web.

2. Hanke, T. and W. Stark, 2009. Strategy Development: Conceptual Framework on Corporate Social Responsibility. Journal of Business Ethics, web.

3. Chaudhri and Wang, 2007. Communicating CSR on the Internet A Case Study of the Top 100 Information Technology Companies in India, Management Communication Quarterly, 21(2): 232-247.

4. Saeed, 2010. Corporate Social Performance of Indian FMCG Companies, Issues in Social and Environmental Accounting, 3:2.

5. Ascoli, Kimberly, and Tamar Benzaken., Aug. 2009, Web. "Public Policy and the Promotion of Corporate Social Responsibility." DR-CAFTA Responsible Competitiveness. N.p.

6. Bhave, Ajay, 2009, Web. "Experiences of the Role of Government in Promoting CSR Initiatives in the Private Sector." Lund University Publications. European Commission's Erasmus Mundus Programme. 


\section{Websites:-}

1. www.econpapers.com

2. www.havardbusiness.org

3. www.tatasteel.com

4. www.smartphilanthrophy.com

5. www.timesfoundation.com

6. www.slideserve.co.uk 